\title{
GAMBARAN DARAH DAN HISTOPATOLOGI INSANG, USUS DAN OTAK IKAN KOI (Cyprinus carpio koi) YANG DIINFEKSI SPORA Myxobolus koi SECARA ORAL
}

\section{HAEMATOLOGY AND HISTOPATOLOGY OF GILLS, INTESTINE AND BRAIN KOI FISH (Cyprinus carpio koi) Myxobolus koi ORALLY INFECTED}

\author{
Era Insivitawati ${ }^{1}$, Gunanti Mahasri $^{2}$ dan Kusnoto ${ }^{3}$ \\ ${ }^{1}$ Sekolah Pascasarjana Universitas Airlangga \\ Kampus B J1. Airlangga 4-6 Surabaya, 60286 Telp. 031-5041566 \\ ${ }^{2}$ Fakultas Perikanan dan Kelautan Universitas Airlangga \\ Kampus C Mulyorejo - Surabaya, 60115 Telp. 031-5033710 \\ ${ }^{3}$ Fakultas Kedokteran Hewan Universitas Airlangga \\ Kampus C Mulyorejo - Surabaya, 60115
}

\begin{abstract}
Koi fish (Cyprinus carpio koi) is one of the ornamental fish are preferred. One of the obstalces in the koi fish is a disease caused by infection myxobollus. This research to determine the effect of the infection myxobollus by oral in blood picture and histopathology. Haematology and histopathology is an indicator of the health of the fish to diagnose disease and to determine changes in the fish tissue.

The research was conducted in Politeknik Kelautan dan Perikanan, dan Balai Karantina Ikan Kelas I, Juanda Surabaya from October to December 2014. This study uses the 5 treatments and 5 replications with different doses of infection $(0,60,80,100$ and $120 \mathrm{spora} /$ fish $)$. Data were analyzed with Annova haematology, followed by Duncan $5 \%$. While histopathology were analyzed by semiquantitative scoring mothod used to determine the degree of histology Kluschal Wallis. The result showed that the haematology has significant result, white histopathology signify the presence of significant damage.
\end{abstract}

Keywords : Koi Fish (Cyprinus carpio koi), Myxobolus, Haematology and Histopatology

\section{Pendahuluan}

Perkembangan usaha perikanan di Indonesia saat ini semakin pesat, hal ini ditunjukkan dengan semakin meningkatnya usaha perikanan, baik dari usaha budidaya, penangkapan hingga industri pengolahan produk perikanan. Koi merupakan salah satu jenis ikan hias yang memiliki potensi untuk dikembangkan dan memiliki jenis dan warnawarni yang menarik sehingga menjadi daya tarik bagi penggemar ikan hias.

Dayat dan Sitanggung, (2004) menyatakan bahwa peluang pasar ikan hias , khususnya pemintaan konsumen terhadap koi lokal tidak pernah sepi sehingga para pembudidaya koi di jawa timur terus-menerus melakukan pembudidayaan, bahkan hingga kesulitan dalam memenuhi permintaan pasar. Tingginya permintaan pasar tersebut meningkatkan harga ikan di pasaran.

(Dinas Perikanan dan Kelautan Kabupaten Blitar, 2012) Produksi ikan koi di kabupaten Blitar mencapai 647.000 ekor. Saat ini pembudidayaan ikan koi tidak hanya di kecamatan Nglegok saja, namun mulai menyebar di kecamatan Sanankulon, Selopuro, Gandusari, Ponggok dan Wlingi.
Usaha budidaya memiliki banyak kendala dalam memenuhi kebutuhan pasar. Kendala yang utama umumnya disebabkan oleh ancaman hama dan penyakit. Salah satu penyakit yang banyak ditemukan pada ikan koi adalah myxobolusis yang disebabkan oleh Myxobolus sp. Penyakit ini merupakan penyakit yang berbahaya, karena dapat mengakibatkan kematian ikan. Sampai saat ini belum ada obat yang efektif untuk ikan yang terinfeksi species ini.

Myxobolusis merupakan penyakit yang mengancam keberhasilan budidaya ikan koi. Menurut Mulyana et al. (1990) dikutip oleh Irianto dan Madya (2012), infeksi Myxobolus koi dapat menyebabkan kematian sekitar 50\% dari populasi. Hal tersebut menunjukkan bahwa Myxobolus sp. dapat merugikan dan berbahaya bagi usaha budidaya ikan koi. Gejala klinis yang terjadi pada ikan terserang Myxobulus sp. adalah adanya benjolan (bisul) pada bagian insang dan mengeluarkan cairan keruh berwarna kemerahan seperti nanah (Bachtiar, 2002). Nodul yang terdapat pada insang akan mengganggu suplai oksigen ke dalam darah, kondisi ikan akan semakin parah ketika nodul pecah sehingga menyebabkan nekrosis pada 
jaringan karena fungsi pernafasan terganggu. Tahun 2012 pernah terjadi kematian masal di daerah Sleman dan Kulon Progo yang disebabkan oleh infeksi Myxobolus. Infeksi Myxobolus koi dapat menyebabkan kematian sekitar 50\% dari populasi (Irianto, 2012).

Darah merupakan salah satu bagian yang terdapat pada ikan yang dapat digunakan sebagai indikator untuk mengetahui tingkat kesehatan ikan. Sesuai dengan pernyataan Salasia et al. (2001) bahwa gambaran normal darah ikan diperlukan untuk menentukan status kesehatan dan membantu diagnosis penyakit pada ikan.

Pemeriksaan histopatologi merupakan teknik pemeriksaan dengan mempelajari perubahan abnormal sel atau jaringan yang digunakan untuk menentukan diagnosis penyakit pada ikan (Mohammadi et al., dikutip oleh Sudaryatma et al., 2012).

Pemeriksaan histopatologi pada ikan dapat memberikan gambaran perubahan jaringan ikan yang terinfeksi penyakit. Dalam penentuan penyakit pada ikan, diagnosis penyakit merupakan langkah awal yang perlu diterapkan (Asniatih, 2013), oleh sebab itu perlu dilakukan penelitian mengenai gambaran darah dan histopatologi ikan untuk mengetahui kondisi kesehatan ikan.

\section{Materi dan Metode}

Penelitian ini dilaksanakan di Laboratorium Pembenihan dan Laboratorium Hama dan Penyakit Ikan Akademi Perikanan Sidoarjo (APS) dan di Laboratoriun Histologi Balai Karantina Ikan dan Pengendalian Mutu Kelas I Juanda, Surabaya pada September hingga Oktober 2014. Peralatan yang digunakan dalam penelitian ini antara lain: akuarium, gelas ukur, bak ember plastik, sechio set, obyek glass, pipet tetes, haemocytometer, tabung sahli, mikroskop, obyek glass, cover glass, srynge (suntikan), kantong plastik, selang dan batu aerasi, termometer air, DO meter, $\mathrm{pH}$ meter, mikrotome, Lieca biosystem tissue processor, wax dispenser, wadah Plastik.

Bahan yang digunakan dalam penelitian ini antara lain: Ikan mas (Cyprinus carpio) sehat, ikan mas (Cyprinus carpio) terinfeksi Myxobollus, antikoagulan EDTA, etanol $70 \%$, etanol $80 \%$, etanol $85 \%$, etanol $100 \%$, Xylene, parafin cair, Formalin 10\%, alkohol 95\%, alkohol 100\%, Acid alkohol, Hematoxylin, Eosin, Larutan Davidson, aquadest, giemsa.

Penelitian ini adalah jenis true eksperimental dengan menggunakan post test only control group design. Penelitian ini dilakukan dengan menggunakan 5 perlakuan dan masing-masing perlakuan dilakukan 5 ulangan, perlakuan dilakukan dengan pemberian dosis infeksi Myxobollus koi yang berbeda, antara lain:

1. Perlakuan A dengan Tanpa pemberian infeksi Myxobollus koi (kontrol)

2. Perlakuan B dengan pemerian dosis infeksi Myxobollus koi 60 spora/ikan.

3. Perlakuan $\mathrm{C}$ dengan pemerian dosis infeksi Myxobollus koi 80 spora/ikan.

4. Perlakuan D dengan pemerian dosis infeksi Myxobollus koi 100 spora/ikan.

5. Perlakuan E dengan pemerian dosis infeksi Myxobollus koi 120 spora/ikan.

Pelaksanaan Penelitian

Persiapan dan Perlakuan Ikan Selama Penelitian Sebelum digunakan akuarium dicuci dan diberi $\mathrm{KmnO} 4$ 0,125 ppm sebagai desinfektan, selanjutnya masing-masing akuarium diisi dengan air PDAM yang sudah dilakukan penyaringan sebanyak 3 liter.

Ikan mas yang telah didapat dari kolam di Desa Kemloko, Kecamatan Nglegok, Kabupaten Blitar, Jawa Timur, dibawa ke laboratorium pembenihan Akademi Perikanan Sidoarjo menggunakan kantong plastik tertutup dengan penambahan oksigen sebanyak 2 kali dari tinggi air di dalam plastik. Sebelum ikan mas digunakan untuk penelitian dilakukan aklimatisasi selama 3 hari.

Ikan yang terinfeksi Myxobolus diperiksa nodul pada insangnya dan diambil nodul tersebut dan diletakkan pada wadah. Selanjutnya nodul dipecah dengan menggunakan pinset, ditambahkan dengan aquadest dan dilakukan pengenceran dan diamati dibawah mikroskop untuk mengetahui jumlah yang akan diberikan sesuai dosis yang diinginkan, kemudian nodul yang tidak langsung digunakan direndam dalam larutan buffer Phosphat dan disimpan dalam freezer.

Selanjutnya dilakukan perlakuan dengan menginfeksi ikan yang sehat menggunakan paparan Myxobolus infeksi buatan dengan dosis 60 spora/ikan, 80 spora/ikan, 100 spora/ikan, 120 spora/ikan dan tanpa pemberian spora Myxobollus sebagai kontrol. Spora Myxobollus diberikan secara oral dan dilakukan selama 7 hari, dan kontrol kualitas air dilakukan setiap hari, pagi dan sore.

Pemeriksaan Gambaran Darah Pengambilan Darah

Pengambilan darah ikan dilakukan dengan cara Spuit diisi dengan EDTA (Etylene Diamine Tetraacetic Acid) agar darah yang 
diambil tidak membeku. Selanjutnya ikan disiapkan dan diambil darahnya dengan cara pengambilan darah yaitu spuit ditusukkan pada bagian linea lateralis dengan kemiringan $45^{\circ}$, lalu darah diambil dengan spuit secara perlahan, sehingga didapatkan darah yang diinginkan. Tempat pengambilan darah ikan dapat dilakukan pada daerah Linea Lateralis, dorsal ventralis, caudal peduncle dan jantung. ( Rahmatullah, 2010).

\section{Perhitungan Kadar Hemoglobin}

Pengukuran kadar Hemoglobin (Hb) dilakukan dengan metode Sahli yang mengkonversi darah ke dalam bentuk asam hematin setelah darah ditambah dengan $\mathrm{HCl}$. Pertama darah dihisap dengan pipet sahli sampai skala $20 \mathrm{~mm}^{3}$ atau pada skala $0.02 \mathrm{ml}$, kemudian darah dipindahkan ke dalam tabung $\mathrm{Hb}$-meter yang telah diisi $\mathrm{HCl} 0.1 \mathrm{~N}$ sampai skala 10, aduk dan dibiarkan selama 3- 5 menit.

Setelah itu aquades ditambahkan sampai warna darah dan $\mathrm{HCl}$ tersebut seperti warna larutan standar yang ada dalam $\mathrm{Hb}$ meter tersebut. Skala dibaca dengan melihat permukaan cairan dan dicocokkan dengan skala tabung sahli yang dilihat pada skala jalur gr\% (kuning) yang berarti banyaknya hemoglobin dalam gram per $100 \mathrm{ml}$ darah (Maswan, 2009).

\section{Perhitungan Kadar Hematokrit}

Darah dihisap dengan tabung mikrohematokrit sampai mencapai $3 / 4$ bagian tabung. Kemudian ujung tabung ditutup dengan crytoseal sedalam $1 \mathrm{~mm}$, sehingga terbentuk sumbat crytoseal. Selanjutnya tabung mikrohematokrit disentrifus dengan kecepatan $5000 \mathrm{rpm}$ selama 5 menit dengan posisi tabung yang bervolume sama berhadapan agar putaran sentrifuse seimbang. Nilai kadar hematokrit ditentukan dengan persentase panjang bagian darah yang mengendap (a) dan panjang total volume darah yang terdapat di dalam tabung (b). Sehingga kadar Hematokrit $=(\mathrm{a} / \mathrm{b}) \mathrm{x}$ 100\% (Chinabut et al. 1991 dikutip oleh Maswan, 2009)

\section{Penghitungan Total Eritrosit}

Darah dihisap dengan pipet yang berisi bulir pengaduk warna merah sampai skala 0,5). Lalu tambahkan larutan Hayem's (berfungsi untuk mematikan sel-sel darah putih) sampai skala 1:1, pengadukan darah di dalam pipet dilakukan dengan mengayunkan tangan yang memegang pipet seperti membentuk angka delapan selama 3 - 5 menit sehingga darah tercampur rata. Setelah itu tetesan pertama larutan darah dalam pipet dibuang, selanjutnya teteskan pada haemacytometer tipe Neubauer kemudian ditutup dengan gelas penutup. Jumlah sel darah merah dengan bantuan mikroskop dengan perbesaran 400 x. Menurut Nabib \& Pasaribu (1989) dikutip oleh Maswan (2009), jumlah eritrosit total dihitung pada 5 kotak kecil haemacytometer dan jumlahnya di hitung dengan rumus : Jumlah eritrosit $=(\mathrm{A} / \mathrm{N}) \times(1 / \mathrm{V})$ $\mathrm{x}$ Fp; Keterangan : $\mathrm{A}=\Sigma$ sel terhitung, $\mathrm{V}=$ volume kotak haemacytometer, $\mathrm{N}=\Sigma$ kotak haemacytometer yang diamati, Fp $=$ Faktor pengenceran

\section{Penghitungan Total Leukosit}

Darah dihisap dengan pipet yang berisi bulir pengaduk warna putih sampai skala 0,5 . Lalu tambahkan larutan Turk's (berfungsi untuk mematikan sel-sel darah merah) sampai skala 11 , pengadukan darah di dalam pipet dilakukan dengan mengayunkan tangan yang memegang pipet seperti membentuk angka delapan selama 3 - 5 menit sehingga darah tercampur rata. Setelah itu tetesan pertama larutan darah dalam pipet dibuang, selanjutnya teteskan pada haemacytometer tipe Neubauer kemudian ditutup dengan gelas penutup. Jumlah sel darah putih dengan bantuan mikroskop dengan perbesaran 400 x. Menurut Svobodova \& Vyukusova (1991) dikutip oleh Mazwan (2009), jumlah leukosit total dihitung sebanyak 5 kotak besar dan dan jumlahnya dihitung dengan rumus : Total Leukosit $=$ jumlah sel terhitung $\times 50$ $\mathrm{sel} / \mathrm{mm}^{3}$.

\section{Histopatologi}

Preparasi sampel

Ikan dimatikan dengan menusuk bagian otak, kemudian operkulum digunting dan diambil insangnya, kemudian dibedah dan diambil usus dan otaknya diambil sehingga didapatkan 3 organ dari ikan yang akan diamati secara histopatologi Organ-organ tersebut selanjutnya difiksasi dengan buffer formalin $4 \%$ atau dengan larutan davidson dan selanjutnya dibuat preparat sediaan histologis.

\section{Pembuatan Sediaan Histopatologi}

Sampel insang yang telah difiksasi dalam buffer formalin $4 \%$, kemudian dibuat sediaan histologis (metode parafin dan pewarnaan Hematoksilin-Eosin (HE) dengan tahapan yang dapat Teknik Pemeriksaan Histopatologi Organ Ikan dengan Pewarna Hematoxylin-Eosin menurut Mahasri (2007) dikutip oleh Amalisa (2012), adalah sebagai berikut: Tahap pertama adalah Fiksasi , dimana organ Ikan dipotong kecil-kecil dan difiksasi ke 
dalam larutan 10\% Neutral Buffered Formalin selama 24 jam.Selanjutnya dehidrasi dan clearing, yaitu organ yang telah difiksasi dimasukkan kedalam cassete dan didehidrasi dengan menggunakan alkohol bertingkat: $70 \%$, $80 \%, 85 \%, 90 \%, 95 \%$, alkoho; absolut I dan II masing-masing selama 2 jam. Clearing dengan menggunakan Xylene I, II dan III. Kemudian Tahap Impregnasi, organ dimasukkan ke dalam paraffin cair I, II, dan III masing-masing 30 menit.

Selanjutnya tahap Embedding, organ dimasukkan ke dalam cetakan-cetakan besi (base mold yang telah dipanaskan diatas hot plate dan sudah diisi dengan paraffin cair, biarkan hingga paraffin membeku (mengeras. Kemudian tahap Sectioning yaitu Blok paraffin yang telah mengeras diiris dengan menggunakan microtome dengan ketebalan 2-3 $\mu \mathrm{m}$, hasil irisan dicelupkan kedalam air hangat dengan suhu $42-45^{\circ} \mathrm{C}$ sampai jaringan mengembang. Kemudian diletakkan diatas gelas obyek glas dan dikeringkan. Selanjutnya tahap Staining, jaringan yang telah tertempel pada obyek glas dimasukkan kedalam xylene I dan II masing-masing selama 5 menit, alcohol absolut I, II dan 95\% selama 1 menit. Kemudian diwarnai dengan Hematoxylin selama 10 menit, ke dalam akuades 4 celupan, acid alcohol 4 celupan dan air mengalir 10 menit. Kemudian diwarnai dena Eosin selama 2 menit, dimasukkan kedalam alcohol 95\% I dan II masing-masing 2 celupan, alcohol absolut I dan II masing-masing I, II dan III masing-masing 2 Menit.

Selanjutnya tahap Pengamatan yang dilakukan dibawah mikroskop cahaya dengan perbesaran $100 \mathrm{x}$ dan 400x.4.5.3 Pemeriksaan Histopatologi Insang, Usus dan Otak Pengamatan secara mikroskopis preparat irisan histologi insang dan usus diamati dengan menggunakan mikroskop dengan perbesaran 40100 kali, dan diamati perubahan dan kerusakan jaringan pada insang, usus dan otak ikan koi. Parameter
Parameter utama dalam penelitian ini adalah profil darah ikan meliputi nilai haemoglobin, leukosit, eritrosit, hematokrit, limfosit dan gambaran histopatologi insang, usus dan otak. Sedangkan parameter pendukung adalah kualitas air.

\section{Analisis Data}

Data pemeriksaan gambaran darah ikan berupa nilai kadar haemoglobin, leukosit, eritrosit, hematokrit, limfosit dengan uji F yang dilanjutkan dengan uji Duncan 5\%. Sedangkan histopatologi dianalisis dengan metode semiquantitative scoring perubahan histopatologi, yaitu scoring yang digunakan untuk menentukan tingkat kerusakan histopatologi Kluschal wallis yang dilanjutkan dengan uji T untuk perbandingan.

\section{Hasil dan Pembahasan}

Hasil penelitian didapatkan data perhitungan gambaran darah yang dapat dilihat pada Tabel 1 .

Leukosit

Hasil analisa data perhitungan leukosit yang dianalisis dengan Anova dapat diketahui bahwa terdapat perbedaan yang signifikan $(\mathrm{p}<0,05)$ terhadap perlakuan pemberian dosis infeksi yang berbeda. Berdasarkan uji Duncan $5 \%$, diketahui bahwa limfosit ikan koi tertinggi didapatkan dari ikan yang diinfeksi dengan dosis 120 spora/ikan yaitu sebesar $188800 \pm$ 8500. Jumlah leukosit perakuan D dengan dosis 100 spora/ikan menunjukkan hasil yang tidak signifikan dengan perlakuan $\mathrm{C}$ yang diinfeksi dengan dosis 80 spora/ikan. Sedangkan jumlah leukosit terendah adalah ikan yang tanpa pemberian infeksi spora myxobollus yang menunjukkan hasil yang tidak signifikan terhadap perlakuan B yaitu ikan yang diinfeksi dengan dosis 60 spora/ikan.

Nilai kadar leukosit dalam darah dapat digunakan untuk mengetahui sistem pertahanan tubuh ikan dari gangguan luar, termasuk pathogen. Dari penelitian ini diketahui hasil

Tabel 1. Data Gambaran Darah Ikan Koi

\begin{tabular}{|c|c|c|c|c|c|}
\hline \multirow[b]{3}{*}{ Perlakuan } & \multicolumn{5}{|c|}{ Gambaran Darah Ikan Koi } \\
\hline & \multicolumn{5}{|c|}{ Rata-rata + SD } \\
\hline & Leukosit & Eritrosit & Hematokrit & Trombosit & Haemoglobin \\
\hline A & $63500^{a}+29089$ & $0,502^{\mathrm{a}}+0,46143$ & $2,254^{a}+0,816$ & $17100^{a}+60725$ & $4,0600+2,090$ \\
\hline B & $109650^{a b}+44750$ & $0,690^{a b}+0,37000$ & $3,133^{b}+0,903$ & $39000^{a b}+8000$ & $3,8500+1,250$ \\
\hline $\mathrm{C}$ & $167900 b c+71700$ & $1,335^{a b}+0,30500$ & $4,627^{b c}+0,651$ & $65000^{b c}+13000$ & $3,6000+0,300$ \\
\hline $\mathrm{D}$ & $158050^{b c}+39150$ & $1,130^{a b}+0,64000$ & $4,007^{b c}+1,458$ & $108500^{b c}+12500$ & $3,3000+1,150$ \\
\hline $\mathrm{E}$ & $188800^{c}+8500$ & $1,275^{b}+0,02$ & $4,764^{c}+0,045$ & $110500^{c}+28500$ & $3,7000+1,250$ \\
\hline
\end{tabular}


pengujian kandungan leukosit pada darah ikan pada perlakuan A dan B enunjukkan nilai leukosit berkisar antara 20.000-150.000 sel/mm3, sedangkan perlakuan $\mathrm{C}$ dan $\mathrm{D}$ terus meningkat, hingga didapatkan nilai leukosit tertinggi pada perlakuan $\mathrm{E}$ dengan ratarata174.500. Menurut Moyle dan Chech (1988) dikutip oleh Sarjito, dkk (2013), bahwa kan yang normal memiliki jumlah leukosit normal sebanyak $20.000-150.000 \mathrm{sel} / \mathrm{mm} 3$. (Moyle dan Chech 1988 dikutip oleh Sarjito, dkk 2013)

Jumlah leukosit yang meningkat sesuai dengan meningkatnya dosis infeksi ikan menunjukkan bahwa semkin besar dosis infeksi myxobollus, maka akan semakin menurunkan tingkat kesehatan ikan. Leukosit digunakan sebagai indikator kesehatan ikan karena leukosit sebagai system pertahanan tubuh ikan dari gangguan luar, termasuk pathogen, stress, leukemia atau parasit. Hal ini sesuai dengan pernyataan Anderson dan Siwicki (1993) dikutip oleh Syawal et al. (2008), bahwa terjadinya peningkatan jumlah leukosit dapat dijadikan sebagai tanda adanya infeksi, stres maupun leukimia. Respon tersebut juga akan muncul akibat adanya beberapa faktor seperti trauma, bahan kimia, toksin, parasit, bakteri, dan virus.

\section{Eritrosit}

Hasil analisa data perhitungan jumlah eritrosit pada ikan koi yang dianalisis dengan Anova menunjukan hasil yang tidak signifikan terhadap pemberian dosis infeksi myxobollus yang berbeda tiap perlakuan.

Berdasarkan hasil uji Duncan 5\% diketahui bahwa jumlah eritrosit pada perlakuan A yaitu tanpa pemberian infeksi spora menunjukkan hasil yang signifikan terhadap perlakuan E yang diinfeksi Myxobollus dengan dosis 120 spora/ikan. Sedangkan Pada perlakuan B,C dan D menunjukkan hasil jumlah eritrosit yang tidak signifikan.

Hasil penelitian menunjukan bahwa infeksi myxobolus berpengaruh pada peningkatan kandungan eritrosit, dimana kandungan rerata eritrosit pada darah ikan yang terinfeksi myxobolus mengalami peningkatan dibanding dengan yang tidak terinfeks. Hasil menunjukkan bahwa semua perlakuan yang diinfeksi spora myxobolus mempunyai kandungan eritrosit pada darah lebih tinggi dari ikan yang tidak terinfeksi myxobolus. Lebih jelasnya diagram kandungan eritrosit setiap perlakuan.

Dari gambar diatas dapat dijelaskan bahwa setiap ikan yang terinfeksi Myxobolus akan mengalami peningkatan jumlah eritrosit dalam darah, dan peningkatan eritrosit ini tergantung dari dosis infeksi spora/ikan. Jumlah kandungan eritrosit dalam darah akan meningkat seiring dengan peningkatan dosis infeksi pada ikan, hal ini disebabkan karena ikan yang mengalami stress akan mempunyai kandungan eritosit lebih tinggi. Hal tersebut sesuai dengan pernyataan Wedemeyer, (1997) yang dikutip oleh Syawal et al. (2008), bahwa eritrosit yang terlalu tinggi mengindikasikan ikan dalam keadaan stres.

\section{Hematokrit}

Setelah data di transformasi dan di analisa dengan Anava, hasil menunjukkan bahwa perbedaan dosis infeksi myxobollus menunjukkan perbedaan yang sangat signifikan $(<0,01)$

Berdasarkan hasil uji Duncan 5\% diketahui bahwa jumlah hematokrit pada perlakuan A yaitu tanpa pemberian infeksi spora menunjukkan hasil yang signifikan terhadap perlakuan E yang diinfeksi Myxobollus dengan dosis 120 spora/ikan. Sedangkan hematokrit pada perlakuan B,C dan D menunjukkan hasil yang signifikan.

Hasil penelitian menunjukkan bahwa infeksi myxobolus berpengaruh pada nilai hematrokrit dalam darah ikan, seiring dengan tingkatan pada perlakuan dosis infeksi yang berbeda. Data menunjukkan bahwa semua perlakuan yang terinfeksi spora myxobolus mengalami peningkatan hematokrit, tergantung dari tingkat stress ikan. Sedangkan jumlah hematokrit < $30 \%$ merupakan defresiasi eritrosit, oleh sebab itu hasil uji hematokrit akan berkorelasi dengan hasil uji eritrosit.

Trombosit

Hasil analisa data perhitungan jumlah trombosit pada ikan koi yang dianalisis dengan Anova menunjukan hasil yang signifikan $(<0,05)$ terhadap pemberian dosis infeksi myxobollus yang berbeda tiap perlakuan.

Berdasarkan hasil uji Duncan 5\% diketahui bahwa jumlah trombosit pada perlakuan A yaitu tanpa pemberian infeksi spora menunjukkan hasil yang signifikan terhadap perlakuan E yang diinfeksi Myxobollus dengan dosis 120 spora/ikan. Sedangkan pada perlakuan A dan B menunjukkan hasil yang tidak signifikan, hasil yang tidak signifikan juga terdapat pada perlakuan $\mathrm{C}$ dan $\mathrm{D}$ menunjukkan hasil jumlah eritrosit yang tidak signifikan.

Trombosit merupakan sel pembeku darah. Dari penelitian ini diperoleh bahwa kandungan trombosit ikan pada setiap perlakuan menunjukan hasil yang berbeda. Data 
menunjukkan bahwa pada setiap peningkatan dosis infeksi yang diberikan dari setiap perlakuan (perlakuan B,C,D dan E) menunjukan kandungan trombosit dalam darah yang berbeda, hal ini disebabkan karena adanya infeksi ini, darah akan berusaha untuk membetuk ketahanan dengan meningkatnya jumlah trombosit sebagai sel pembeku darah. Namun demikian pada ikan yang tidak terserang infeksi pathogen, juga dapat mengalami stress atau membentuk pertahanan dengan meningkatnya kandungan trombosit, seperti halnya perlakuan A (kontrol), nilai trombosit yang tinggi menandakan ikan dalam kondisi stress.

\section{Haemoglobin}

Hasil analisa data perhitungan jumlah haemoglobin pada ikan koi yang dianalisis dengan Anova menunjukan hasil yang tidak signifikan $(>0,05)$ terhadap pemberian dosis infeksi myxobollus yang berbeda tiap perlakuan. Berdasarkan hasil uji Duncan 5\% diketahui bahwa jumlah haemoglobin pada semua perlakuan menunjukkan hasil jumlah haemoglobin yang tidak signifikan.

Haemoglobin sangat berperan dalam mengikat oksigen untuk katabolisme yang akan menghasilkan energi, dengan demikian rendahnya haemogobin dapat menurunkan daya tahan ikan yang pada akhirnya dapat menyebabkan kematian.
Hasil pengukuran haemoglobin menunjukkan bahwa pada setiap perlakuan yang diberi infeksi spora myxobolus, akan menunjukan kandungan hemoglobin yang lebih rendah dari ikan yang tidak terinfeksi. Hal ini menunjukan bahwa semakin tinggi dosis infeksi spora pada ikan akan semakin banyak tumbuh myxobolus pada bagian insang, yang berakibat semakin rendahnya haemoglobin pada darah. Hal ini dikarenakan semakin rendah haemoglobin pada ikan, berarti insang sedang terganggu, atau mengalami kerusakan.

\section{Histopatologi}

Dari hasil penelitian didapatkan Nilai skoring untuk perubahan histopatologi insang, usus dan otak ikan koi dapat dilihat pada Tabel 2.

Dari hasil penjabaran pada Tabel 2 . diketahui bahwa kerusakan histopatologi terberat adalah pada bagian insang ikan koi dari perlakuan $\mathrm{E}$ yang diberikan dosis tertinggi sebanyak 120 spora/ekor,yaitu haemoragi, nekrosis, dislokasi, hipertropi, dan hiperplasia. Haemoragi (pendarahan) yang ditandai dengan keluarnya darah dari vaskula akibat kerusakan dari dinding vaskula. Sedangkan nekrosis adalah kematian sel yang ditandai dengan adanya inti sel yang tidak tampak, tidak dapat diwarnai atau hilang. Hasil dari histopatologi juga menunjukkan adanya hipertropi yaitu adanya peningkatan ukuran sel atau sel yang

Tabel 2. Nilai skoring histopatologi insang, usus dan otak

\begin{tabular}{|c|c|l|c|c|c|c|c|l|}
\hline No. & Perlakuan & Organ & \multicolumn{5}{|c|}{ Score } & Keterangan \\
\hline 1 & A & Insang & 0 & 0 & 0 & 0 & 0 & \\
\hline & & Usus & 0 & 0 & 0 & 0 & 0 & \\
\hline & & Otak & 0 & 0 & 0 & 0 & 0 & \\
\hline 2 & B & Insang & 1 & 0 & 1 & 0 & 1 & Haemoragi \\
\hline & & Usus & 0 & 0 & 1 & 1 & 0 & Haemoragi \\
\hline & & Otak & 0 & 0 & 0 & 0 & 0 & \\
\hline 3 & C & Insang & 1 & 1 & 1 & 0 & 0 & Haemoragi \\
\hline & & Usus & 1 & 0 & 1 & 0 & 0 & Haemoragi, dislokasi \\
\hline & & Otak & 0 & 0 & 0 & 0 & 0 & \\
\hline 4 & D & Insang & 2 & 1 & 0 & 0 & 1 & Haemoragi \\
\hline & & Usus & 2 & 2 & 0 & 0 & 1 & Haemoragi, hipertropi \\
\hline & & Otak & 0 & 0 & 0 & 0 & 0 & \\
\hline 5 & E & Insang & 3 & 0 & 0 & 2 & 2 & Haemoragi, hipertropi, hierplasia dan nekrosis \\
\hline & & Usus & 2 & 0 & 0 & 2 & 1 & Haemoragi, nekrosis \\
\hline & & Otak & 0 & 0 & 0 & 0 & 0 & \\
\hline
\end{tabular}

Keterangan : Nilai Skoring perubahan Histopatologi menurut Pantung (2002) dikutip oleh Abdulghani, dkk (2013), adalah sebagai berikut :

Score 0 (normal) : tidak ada sama sekali

Score 1 (ringan) : kurang dari 30\% dari luasan pandang

Score 2 (sedang) : 30-70\% dari luasan pandang

Score 3 (berat) : lebih dari $70 \%$ luasan pandang 

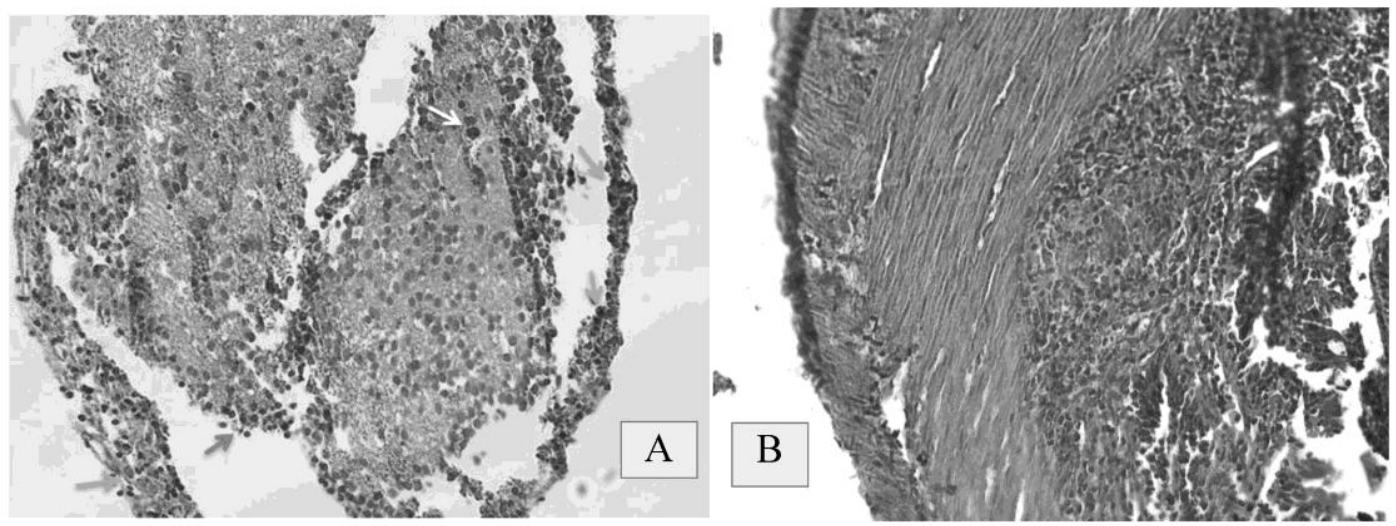

Gambar 1. (A) Histopatologi Usus Ikan Koi yang Terinfeksi Myxobolus (Perbesaran 400X), (B)Histopatologi Otak Ikan Koi yang Terinfeksi Myxobolus (Perbesaran 400X) Keterangan : $\rightarrow$ haemoragi, $\rightarrow$ dislokasi, $\rightarrow$ hiperplasia, $\rightarrow$ nekrosis, $\rightarrow$ hipertropi

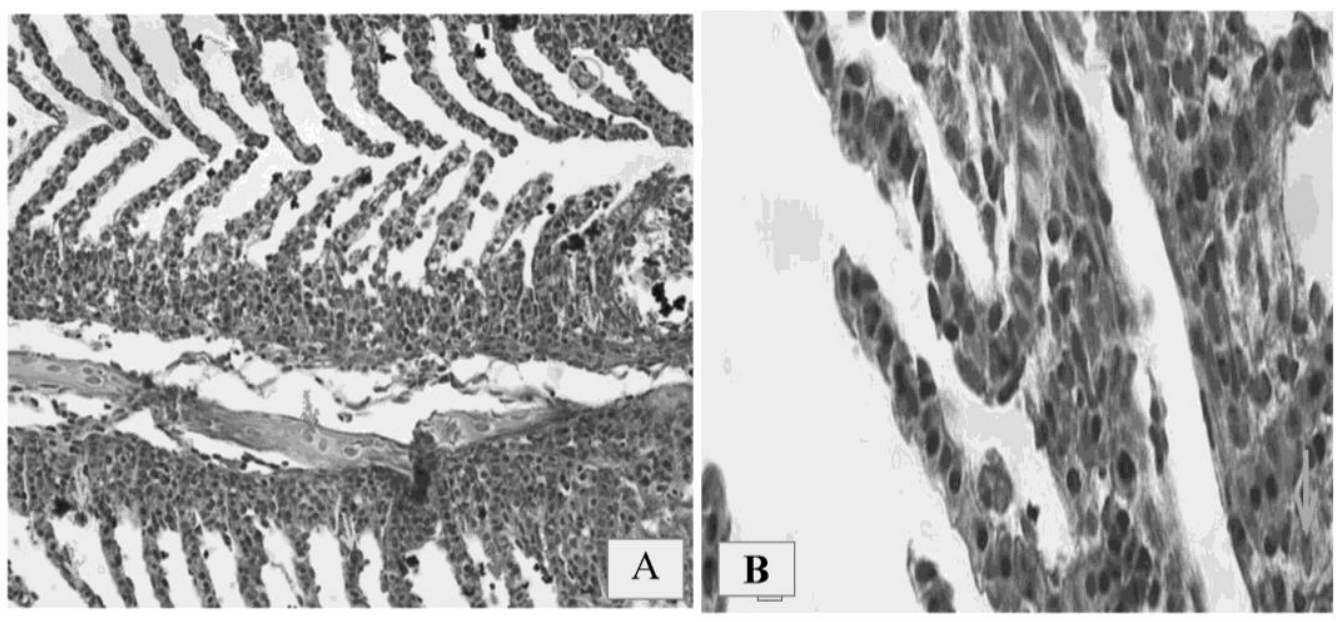

Gambar 2. (A) Histopatologi Insang Ikan Koi yang Terinfeksi Myxobolus (Perbesaran 400X), (B)Histopatologi Insang Ikan Koi yang Terinfeksi Myxobolus (Perbesaran 1000X) Keterangan : $\rightarrow$ haemoragi, $\rightarrow$ dislokasi, $\rightarrow$ hiperplasia, $\rightarrow$ nekrosis, $\rightarrow$ hipertropi

membesar, dan hiperplasia yaitu penambahan jumlah sel.

Dari hasil histopatologi diketahui bahwa ikan yang dipapar dengan myxobolus menunjukkan adanya kerusakan dalam jaringan insang dan ususnya, sedangkan pada otak ikan tidak mengalami perubahan yang berarti. Hal ini menunjukkan bahwa inteksi tersebut telah membuat ikan mengalami gangguan dan perubahan yang ditandai adanya pembengkakan, nekrosis, hipertropi, hiperplasia dan edema. Pembengkakan sel bersifat reversibel sehingga apabila paparan zat toksik tidak belanjut maka sel dapat kembali normal, namun jika zat tersebut berlangsung lama makan sel tidak dapat mentolerir kerusakan yang diakibatkan oleh zat toksin tersebut.
Kualitas Air

Dalam penelitian ini dilakukan mengukuran kualitas air pada setiap hari, untuk mengetahui apakah ada hal-hal yang bersifat ekstrim dan dapat menyebabkan kematian ikan, sedangkan kualitas air yang diukur adalah variable yang dimungkinkan berubah yaitu DO, Suhu dan $\mathrm{pH}$.

Dari data diatas dapat diketahui bahwa tidak terdapat DO ekstrim rendah, karena selama penelitian, air media diberikan aerasi yang cukup, yaitu oksigen terlarut pada kisaran 4 ppm, sehingga kematian ikan sepenuhnya akibat dari perlakuan infeksi spora myxobullus.

Dari data tersebut diatas dapat diketahui bahwa suhu air media cenderung konstan, walaupun ada perubahan harian tetapi relatif kecil, karena penelitian ini dilakukan 
didalam ruangan yang rapat sehingga perubahan suhu luar kecil pengaruhnya pada air media. Selama penelitian tidak terdapat suhu ekstrim pada air media, sehingga kematian ikan sepenuhnya disebabkan oleh perlakuan infeksi spora myxobolus.

Dari data diatas dapat diketahui bahwa tidak terdapat $\mathrm{pH}$ ekstrim yang dapat menyebabkan kematian ikan pada air media penelitian, sehingga kematian ikan murni disebabkan perlakuan infeksi spora myxobolus. Namun demikian sama halnya dengan parameter kualitas air yang lain( DO), $\mathrm{pH}$ mengalami penurunan setelah ada kematian ikan, hal ini menunjukan adanya penurunan kualitas air akibat degradasi protein dari Ikan yang mati.

\section{Kesimpulan}

Hasil penelitian menunjukkan bahwa pemberian infeksi Myxobollus secara oral pada ikan koi dapat memberikan perubahan gambaran darah dan histopatologi pada ikan koi (Cyprinus carpio koi). Terjadi Kerusakan jaringan ikan koi (Cyprinus carpio koi) yang diinfeksi Myxobollus secara oral, kerusakan terparah terdapat pada ikan koi dengan dosis infeksi terbanyak yaitu 120 spora/ikan (perlakuan E). Kerusakan jaringan yang ditemukan antara lain haemoragi, hipertropi, hiperplasia, dislokasi dan nekrosis.

Hasil gambaran darah menunjukkan terjadinya peningkatan jumlah eritrosit dan trombosit pada ikan koi yang terinfeksi Myxobollus menunjukkan bahwa ikan mengalami stres, dan terjadinya peningkatan jumlah leukosit menunjukkan ikan mengalami stres dan terjadi infeksi.

Saran yang dapat diajukan dalam penelitian ini adalah perlunya informasi mengenai pengaruh pemberian infeksi myxobollus perlu dilanjutkan hingga didapatkan solusi dalam hal pengobatan yang tepat, mengingat infeksi myxobollus dapat menyerang dengan cepat sehingga perlu penelitian lebih lanjut untuk mendapatkan solusi penanganan Myxobollus yang cepat dan tepat. Masyarakat juga diharapkan mewaspadai serangan Myxobollus koi terharap Ikan Koi (Cyprinus carpio koi), Myxobollus yang menginfeksi ikan koi dapat mengakibatkan perubahan gambaran darah dan kerusakan pada histopatologi ikan.

\section{Daftar Pustaka}

Afrianto dan Liviawaty.,1992. Pengendalian hama dan Penyakit Ikan. Kanisius. Yogyakarta. 89 hal.
Arie U., dan C. Muharam., 2009. Panen Ikan Mas 2,5 Bulan. Penebar Swadaya. Jakarta. 92 hal.

Amalisa, 2012. Perubahan Patologis Insang dan Usus Ikan Koi (Cyprinus carpio koi) Akibat Infeksi Myxobolus pada Derajat Infeksi Berbeda. Skripsi. Fakultas Perikanan dan Kelautan. Universitas Airlangga. Surabaya.61 hal.

Andrianto T.T., 2005. Pedoman Praktis Budidaya Ikan Mas (Kiat Merintis Usaha Bermodal Kecil). Absolut. Yogyakarta.189 hal.

Asniatih, Idris M., dan Sabilu K. 2013. Studi Histopatologi pada Ikan Lele Dumbo (Clarias bgariepinus) yang Terinfeksi Bakteri Aeromonas Hydrophila. Universitas Halu Oleo. Kendari.

Bastiawan, D; A. Wahid; M. Alifudin, dan I. Agustiawan. 2001. Gambaran Darah Lele Dumbo (Clarias Spp.) yang Diinfeksi Cendawan Aphanomyces Sp. pada $\mathrm{pH}$ yang Berbeda. Jurnal Penelitian Indonesia 7(3) 44-47.

Bachtiar Y., 2002. Pembesaran Ikan Mas di Kolam Air Deras. Agromedia Pustaka. Jakarta. 96 hal.

Cholik M.F., A.G. Jagatraya, R.P.Poernomo, dan A. Jauzi. 2005. Akuakultur Tumpuan Harapan Masa Depan Bangsa.Taman akuarium Air tawar Taman Mini Indonesia Indah. Jakarta. 415 hal.

Dayat M., dan Sitanggang M. 2004. Budidaya Koi Blitar Pengalaman dari Ciganjur. Agromedia Pustaka. Jakarta. 74 hal.

Dyah E.W., Aunurrohim, Nurlita A. 2011. Studi Histopatologi Insang Ikan Mujair (Oreochromis mossambicus) pada Konsentrasi Sublethal Air Lumpur Lapindo. Institut Sepuluh November. Surabaya.

Fujaya Y. 2008. Fisiologi Ikan Dasar Pengembangan Teknik Perikanan. Rineka Cipta. Jakarta. 179 hal.

Handajani dan Samsundari. 2005. Parasit dan Penyakit. UMM Press. Malang. 201 hal.

Hastuti, Arisha Miraka, dan Sarjito. 2012. Identifikasi Agensia Penyebab dan Profil Darah Ikan Gurami (Osphronemus gouramy) yang Terserang Penyakit Bakteri.

Hilda Lu'luin N.D. 2011. Hubungan Derajat Investasi Myxobolus Koi terhadap Jumlah Spora dan Derajat Kerusakan pada Usus Ikan Mas (Cyprinus carpio L.). Universitas Airlangga. Surabaya. 
Irawan A. 2000. Menanggulangi Hama dan Penyakit Ikan Pengendalian, Pencegahan dan Pemberantasan. Aneka. Solo. 82 hal.

Irianto dan Madya, 2012. Waspada Myxobolus Sp. Tipe Baru Parasit Pada Ikan Mas (Cyprinus carpo) Di Ngrajek Jawa Tengah. www.badandiklat.jatengprov. go.id. Diakses 2 Januari 2015.

Khairuman, D. Sudenda, dan B. Gunadi., 2008. Budi Daya Ikan Mas Secara Intensif. PT.Agromedia Pustaka. Jakarta. 99 hal.

Kordi. 2004. Penanggulangan Hama dan Penyakit Ikan. Rineka Cipta dan Bina Adiaksara. 190 hal.

Lesmana D.S. 2003. Mencegah dan Menanggulangi Penyakit Ikan Hias. Penebar Swadaya. Jakarta.

Mahasri, G. 2007. Protein Membran Imunogenik Zoothamnium penaei Sebagai Bahan Pengembangan Imunostimulan pada Udang Windu terhadap Zoothamniosis. Disertasi Program Pasca sarjana. Universitas Airlangga. 284 hal.

Maswan N.A. 2009. Pengujian Efektivitas Dosis Vaksin DNS dan Korelasinya terhadap Parameter Hematologi secara Kuantitatif. Institut Pertanian Bogor. Bogor

Rahmatullah Jefry, 2010. Darah Ikan. Jefrybp09.blogspot.com. Diakses 2 Januari 2015.

Redaksi Agromedia. 2002. Koi si Ikan Panjang Umur. Agromedia Pustaka. Jakarta. 74 hal.

Rivai Harrizul. 2013. Macam-macam Metode Penelitian. Universitas Andalas. Padang.

Santoso B., 1992. Petunjuk Praktis Budidaya Ikan Mas. Kanisius. Yogyakarta. 83 hal.

Saputra H.M., Marusin N., dan Santoso P. 2013. Struktur Histologis Insang dan Kadar Haemoglobin Ikan Asang (Osteochillus hasseltii C.V) di Danau Singkarak dan Maninjau, Sumatera Barat. Universitas Andalas. Padang.

Setiadi Hadi, 2013. Pengaruh Pendekatan Taktis Terhadap Hasil Belajar Lay Up Shoot Dalam Permainan Bolabasket (Stusi Eksperimen Di Kegiatan Ekstra Kulikuler Bolabasket SMP Negeri 2 Arjawinangun). Universitas Pendidikan Indonesia.
Setiawan W., 1988. Intisari Biologi. Ernesco. Bandung. 400 hal.

Setiono K.L., 2010. Hakikat Penelitian. www.liliksetiono.wordpress.com. Diakses 30 November 2010.

Setyowati A., Hidayati D., Awik P.D.N., dan Abdulgani N. 2010. Studi Histopatologi Hati Ikan Belanak (Mugil cephalus) si Muara Sungai Aloo Sidoarjo. Institut Teknologi Sepuluh November. Surabaya.

Subandiyono dan Hastuti Sri. 2011. Performa Hematologis Ikan Lele Dumbo (Clarias gariepinus) dan Kualitas Air Media pada Sistim Budidaya I Penerapan Kolam Biofiltrasi. I Saintek Perikanan Vol. 6 No.2 2011. 15.

Surya Rahardian, 2015. Budidaya Ikan Koi, Cara Pemijahan dan Penetasan Telur. www.bibitikan.net. Diakses 2 Januari 2015.

Susanto H, 2002. Koi. Penebar Swadaya. Jakarta. 78 hal.

Syahailatua D.Y., 2009. Seleksi Bakteri Probiotik sebagai Stimulator Sistem Imun pada Udang Vaname (Litopenaus Vannamei). Institut Pertanian Bogor. Bogor.

Syawal H, Syaifriadiman, Syauqi Hidayah. 2008. Pemberian Ekstrak Kayu Siwak (Salvadora Persica L.) untuk Meningkatkan Kekebalan Ikan Mas (Cyprinus Carpio L.) yang Dipelihara dalam Keramba. ISSN : 1412-033X Januari 2008.

Wijoyo P.M. 2012. Rahasia Sukses Mencegah Kematian Koi. Pustaka Agro Indonesia. Jakarta. 97 hal.

Yuniar Irma, 2013. Produksi Ikan Koi di Kab. Blitar Tahun 2013 Ditargetkan Mencapai 188 Juta Ekor. www.blitarkab.go.id. Diakses 2 Januari 2015. 
Gambaran Darah dan Histopatologi Insang...... 